\title{
KUALIFIKASI MANAJERIAL TEKNIS PRODUKSI TELUR PERUSAHAAN UD. FITRA ABADI DI KECAMATAN LEIHITU KABUPATEN MALUKU TENGAH
}

\author{
Adolf B. Heatubun*, Michel J. Matatula, Marcus Veerman, Heriyanus Yesayas
}

Jurusan Peternakan Fakultas Pertanian, Universitas Pattimura

Jl. Ir. M. Putuhena, Kampus Poka, Ambon, Kode Pos. 97233

* Email: $\underline{\text { adolf_bas@yahoo.com }}$

\begin{abstract}
ABSTRAK
Kemampuan manajerial teknis berproduksi telur para peternak dan manajer perusahaan peternakan merupakan sebuah indikator seberapa baik pelaku usaha mengorganisir kegiatan produksi dan bisnis yang berhasil. Penelitian ini bertujuan mengetahui indikator teknis efisiensi produksi pada perusahaan peternakan ayam petelur UD. Fitra Abadi. Penelitian menggunakan metode survei, lokasi dipilih secara purposive sampling, dan penelitian berlangsung selama 31 hari pada bulan Oktober 2018. Sampel yang digunakan adalah satu blok kandang dengan jumlah induk ayam petelur 2.100 ekor. Hasil penelitian menunjukkan perusahaan ayam petelur UD. Fitra Abadi menerapkan paket teknologi yang lebih rendah kapasitasnya dengan mencampur makanan toko (35\%), pakan jagung (45\%), dan pakan dedak (20\%). Produksi telur yang dihasilkan rata-rata per hari sebanyak 1.738 butir (82,76 \% dari 2.100 ekor ayam) berada di bawah kapasitas terbaik periode puncak bertelur yaitu 95\%. Indikator teknis produksi menunjukkan produksi rata-rata telur per kg makanan 6,43 butir, produksi marginal $-0,3$ butir, dan elastisitas $-0,047$. Efiseinsi produksi perusahaan menjadi negatif, dan perusahaan beroperasi pada fase merugi.
\end{abstract}

Kata kunci: Teknis produksi, teknologi mencampur makanan, efisiensi produksi, fase merugi, produksi telur

\section{QUALIFICATION OF TECHNICAL MANAGERIAL MANUFACTURING OF EGG COMPANY UD. FITRA ABADI, KECAMATAN LEIHITU, CENTRAL MALUKU DISTRICT}

\begin{abstract}
The technical managerial ability to produce eggs from farmers and farm company managers is an indicator of how well businesses organize successful production and business activities. This study aims to determine the technical indicators of production efficiency in the laying hens company UD. Fitra Abadi. The study used a survey method, the location was selected purposively, and the study lasted 31 days in October 2018. The sample used was one cage block with 2,100 hens laying hens. The results showed the laying hens, UD. Fitra Abadi applies a technology package that is lower in capacity by mixing shop food (35\%), corn feed (45\%), and bran feed (20\%). Egg production produced an average of 1,738 eggs per day ( $82.76 \%$ of 2,100 chickens) is below the best capacity of the peak egg-laying period of $95 \%$. Technical indicators of production show the average production of eggs per $\mathrm{kg}$ of food 6.43 eggs, marginal production of -0.3 eggs, and elasticity of -0.047 . The efficiency of the company's production becomes negative, and the company operates in a loss phase.
\end{abstract}

Key words: Technical production, food mixing technology, production efficiency, loss phase, egg production

\section{PENDAHULUAN}

Para peternak dan manajer pada perusahaan peternakan yang mengelola usaha ayam petelur dituntut memiliki kemampuan teknis yang baik guna mencapai tingkat usaha yang menguntungkan. Pencapaian usaha menguntungkan bersumber dari pengelolaan usaha di sisi manajemen dan pengelolaan teknis kegiatan produksi. Glendoh (2001) menyatakan bahwa untuk mendorong pengembangan suatu usaha yang berhasil, diperlukan peningkatan kemampuan manajemen dan kemampuan teknis produksi dari para pengelola usaha.

Dalam pengelolaan produksi, peternak atau perusahaan menghadapi berbagai kegiatan teknis pengelolaan atau pengaturan faktor produksi. Pengaturan atau manajemen penggunaan factor produksi juga berkaitan dengan tingkat teknologi produksi yang digunakan. Karena itu manajemen factor produksi yang dilakukan secara baik diikuti oleh penggunaan tingkat teknologi lebih tinggi akan menjamin pencapaian produksi yang makin tinggi. 
Chigbo (2014) menyatakan manajemen sendiri dilihat sebagai sebuah factor produksi dan merupakan sumber daya ekonomi. Masalah mendasar bagi perusahaan adalah tentang bagaimana mengkoordinasikan dan mengintegrasikan semua factor produksi lainnya untuk pengembangan produksi yang berhasil.

Faktor produksi memegang peranan penting dalam menghasilkan produksi. Makin banyak jumlah input atau factor produksi yang digunakan, maka makin tinggi jumlah produksi yang dihasilkan. Kuantitas factor produksi dan produksi dihubungkan oleh suatu fungsi produksi (Banaeian dan Zangeneh, 2011).

Kristianto, et al., (2012) menyatakan bahwa penggunaan teknologi dalam bidang produksi memiliki peran penting dalam meningkatkan kuantitas atau jumlah produksi. Selanjutnya, peningkatan teknologi yang digunakanakan mendukung pengembangan kapabilitas perusahaan dalam berproduksi, bahkan tidak saja kapabilitas perusahaan melainkan juga kompetensi perusahaan untuk mencapai keunggulan kompetitif dibandingkan perusahaan pesaing lainnya.

Penggunaan tingkat teknologi produksi yang lebih tinggi memungkinkan berbagai efisiensi terjadi diantaranya penggunaan jumlah factor produksi lebih sedikit dan biaya produksi lebih ditekan. Dengan demikian ketika teknologi produksi yang digunakan lebih tinggi, memungkinkan perusahaan dan peternak berproduksi pada tingkat yang lebih efisien dengan jumlah input lebih sedikit, biaya produksi lebih rendah, tingkat produksi lebih tinggi serta peluang keuntungan usaha yang lebih besar.

Reiff, et al., (2002) menyatakan, bahwa mengukur produktivitas dan efisiensi adalah sangat penting ketika mengevaluasi unit produksi dan kinerja suatu perusahaan, atau bahkan seluruh perekonomian. Hal ini memungkinkan kita untuk mengidentifikasi sumber-sumber perbedaan efisiensi dan produktivitas, yang merupakan kebijakan penting yang dirancang untuk meningkatkan kinerja. Produktivitas suatu unit produksi didefinisikan sebagai rasio output terhadap input-inputnya (keduanya teragregasi dalam beberapa cara yang masuk akal secara ekonomi). Produktivitas bervariasi karena perbedaan dalam teknologi produksi, perbedaan dalam efisiensi proses produksi, dan perbedaan dalam lingkungan di mana produksi terjadi.

Burja dan Burja (2016) juga mengatakan hubungan antara ukuran perusahaan dan efisiensi memainkan suatu peranan penting di dalam penelitian ekonomi. Hal ini disebabkan karena ukuran perusahaan dan efisiensi memiliki hubungan erat dan memiliki implikasi pada pembangunan pertanian dan pedesaan.

Penelitian ini bertujuan mengetahui indikator teknis efisiensi produksi pada perusahaan peternakan ayam petelur UD. Fitra Abadi. Hipotesis yang digunakan adalah umumnya perusahaan peternakan ayam petelur sudah memiliki kemampuan tertentu dalam berproduksi telur dengan manajemen teknis pengaturan pemberian makanan dan produksi telur yang relative baik. Namun apakah kemampuan ini sesuai dengan indikator-indikator teknis yang ditunjukkan dalam proses produksi?

\section{BAHAN DAN METODE}

Penelitian ini dilaksanakan pada Perusahaan Ayam Petelur UD. Fitra Abadi yang berlokasi Dusun Hulung, Kecamatan Leihitu, Kabupaten Maluku Tengah, Provinsi Maluku menggunakan metode survei. Lokasi penelitian dipilih secara purposive yaitu sesuai dengan tujuan penelitian yang ingin dicapai dan keberadaan perusahaan ayam petelur yang tersedia. Penelitian berlangsung selama tiga bulan.

Data dikumpukan berdasarkan atas data primer dan sekunder. Data primer dicatat dan diukur setiap hari selama pengumpulan data berlangsung dalam satu bulan (31 hari) yakni pada bulan Oktober 2018 mencakup jumlah produksi telur, pengukuran jumlah pakan yang diberikan (ditimbang), dan jumlah pemberian vitamin / mineral (dalam bentuk air minum). Penelitian ini mengambil sampel pada satu blok kandang dengan ukuran usaha induk ayam petelur sebanyak 2.100 ekor. Untuk ketelitian, makanan ditimbang sebelum diberikan dan juga ditimbang bagian makanan tersisa sebelum diberikan jumlah yang baru di hari berikutnya. Begitu juga dengan vitamin atau mineral dalam air minum, ditimbang sebelum diberikan dan juga ditimbang bagian yang tersisa.

Data sekunder mencakup kondisi umum dan karakteristik perusahaan peternakan ayam petelur, dan lainnya. Data yang dikumpulkan dianalisis dengan perhitungan teknis sesuai indikator-indikator jumlah input, produksi, produksi rata-rata, produksi marginal, dan elastisitas.

Variabel-variabel yang diukur mencakup : (1) Q merupakan jumlah produksi telur (butir); (2) RsJd yaitu jumlah ransum jadi (kg); (3) PkJgg yaitu jumlah pakan jagung (kg); (4) PkDdk yaitu jumlah pakan dedak (kg); (5) AP merupakan produksi rata-rata (butir/kg); (6) MP merupakan marginal produk (butir/kg); dan (7) Ep merupakan elastisitas produksi (indeks).

\section{HASIL DAN PEMBAHASAN}

\section{Deskripsi Perusahaan Peternakan Ayam Petelur UD. Fitra Abadi}

Usaha Dagang (UD) Fitra Abadi merupakan sebuah perusahaan peternakan yang bergerak di bidang produksi telur ayam ras, berlokasi di Dusun Hulung, Kecamatan Leihitu, Kabupaten Maluku Tengah. Sebagai Manajer sekaligus Pemilik perusahaan UD. Fitra Abadi, peternak hanya memiliki tingkat pendidikan SMA umum tetapi cukup memiliki pengalaman dalam berproduksi telur sejak tahun 2000 . Clercq dan Arenius (2006) menyatakan bahwa 
pengetahuan, pengalaman serta pendidikan yang dimiliki individu pengusaha merupakan faktor yang berdampak kuat mendorong seorang pengusaha dan pelaku bisnis untuk bekerja dan melakukan suatu bisnis. Hal ini merupakan modal kepercayaan bagi diri sendiri dalam mengambil keputusan dan memulai bisnis.

Selanjutnya, perusahaan UD. Fitra Abadi mempekerjakan 10 karyawan yang bekerja intensif merawat ternak, memberikan makanan dan minuman, mengumpulkan telur, membuat dan menggiling pakan jagung, melakukan desinfektan dan sanitasi terhadap lingkungan perusahaan, dan lain sebagainya.

Orientasi usaha UD. Fitra Abadi mengarah pada operasi komersil untuk tujuan mengejar profit maksimum dan biaya minimum. Untuk menjamin kelancaran proses produksi, telur yang dihasilkan perusahaan dipasarkan ke beberapa lokasi di Pulau Ambon dan Maluku Tengah. Secara khusus perusahaan telah memiliki segmentasi pasar sehingga tidak menyulitkan dalam pemasaran telur produksi. Setiap produksi telur yang dihasilkan perusahaan langsung disalurkan ke Agen pasar sebagai mitra dari perusahaan.

Aydin, et al., (2007) menyatakan bahwa kinerja pemasaran produk dengan frekuensi yang baik dan lancar akan memberikan dampak yang baik pada siklus produksi baru yang akan dihasilkan dan kemampuan inovasi perusahaan. Perusahaan akan terdorong melakukan pengembangan produk baru ketika saluran pemasaran berlangsung secara baik. Tanpa pemasaran produk dengan lancar menyebabkan produksi tertumpuk dan menghambat proses produksi berikutnya. Kondisi ini selanjutnya akan mempengaruhi kinerja perusahaan.

Perusahaan peternakan ayam petelur UD. Fitra Abadi membangun skala produksi pada perusahaannya berkapasitas 15.000 ekor ayam dewasa. Jumlah kandang sebanyak 8 unit berukuran masing-masing 50 $\mathrm{m} \times 7 \mathrm{~m}$. Fasilitas penunjang perusahaan berupa 5 unit kandang DOC dan gudang penyimpanan makanan dan peralatan. Fasilitas yang tersedia meliputi angkutan dan transportasi diantaranya 3 unit mobil (dam truck dan pick up) untuk pengangkutan bahan makanan dan penjualan telur, mesin pembangkit listrik (genset) dan mesin penggiling pakan. Dengan sejumlah fasilitas yang dimiliki ini, perusahaan mampu beroperasi dengan baik dalam memproduksi telur ayam.

\section{Keputusan Teknis Manajemen Produksi UD. Fitra Abadi}

Berbekal pengalaman memelihara ayam ras petelur dan memproduksi telur ayam sejak tahun 2000 , perusahaan membuat program kombinasi makanan guna menghemat biaya produksi. Jenis pakan yang diberikan kepada ternak tidak lagi murni (100\%) makanan atau ransum toko tetapi dikombinasikan dengan pakan jagung (digiling sendiri) dan pakan dedak. Keputusan teknis perusahaan ini merupakan sebuah paket penerapan teknologi baru pada perusahaan dan diyakini memberikan hasil produksi telur cukup tinggi dan keuntungan relatif besar.

Sementara seperti yang diketahui, ransum jadi dari toko adalah ransum yang disusun oleh Perusahaan Makanan Ternak (Comfeed) dengan formulasi dan komposisi kandungan zat-zat gizi yang lengkap dan sudah dirancang sesuai dengan kebutuhan pertumbuhan dan produksi ternak pada berbagai periode umur ternak. Dengan demikian paket teknologi seperti ini seharusnya lebih unggul namun dinilai oleh perusahaan UD. Fitra Abadi lebih mahal dan tidak efisien dalam hal penghematan biaya produksi. Oleh karena itu paket teknologi pemberian makanan kepada ternak yang murni $(100 \%)$ ransum toko ditinggalkan perusahaan dan diganti paket teknologi produksi perusahaan yakni pencampuran makanan.

Sedangkan pakan jagung yang digiling sendiri oleh peternak memiliki kandungan zat-zat gizi hanya parsial sesuai yang dikandung bahan baku. Sesuai pengetahuan peternak, pemberian pakan jagung yang dominan dapat memberikan produksi telur yang banyak. Praktek pemberian makanan kepada ayam petelur dalam bentuk campuran sebagai berikut: makanan toko atau ransum jadi sebanyak 35\%, pakan jagung sebanyak $45 \%$, dan pakan dedak sebanyak $20 \%$.

Informasi harga ransum yang dibeli perusahaan di pasaran mencakup makanan toko per kilogram sebesar Rp. 7.600, pakan jagung Rp. 5.000 per kilogram, dan pakan dedak Rp. 2.500 - Rp. 3.000 per kilogram. Realitas harga jagung yang lebih rendah dibanding ransum toko dan pengetahuan peternak bahwa pakan jagung dapat merangsang produksi telur lebih banyak mendorong peternak membuat program campuran makanan seperti yang dijelaskan di atas. Oleh karena perusahaan membeli makanan baik makanan toko maupun pakan jagung dan dedak dalam partai besar, perusahaan menerima diskon biaya makanan yang cukupbesar. Menurut analisis perusahaan UD. Fitra Abadi, dengan paket teknologi pencampuran makanan, harga rata-rata per kilogram makanan yang dikeluarkan perusahaan sebesar $\mathrm{Rp}$ 5.200. Ini adalah biaya makanan yang rendah dan perusahaan dapat menghemat banyak biaya serta menghasilkan efisiensi.

Informasi tentang harga telur di pasaran saat ini sebesar Rp. 2.000,- per putir. Sementara perusahaan menjual telur di lokasi perusahaan berkisar antara Rp. 1.500 - Rp. 1.800 per butir. Hal ini membuat banyak pembeli langsung datang membeli telur di lokasi perusahaan. Karena harga telur sering berfluktuasi di pasaran maka keuntungan yang diterima peternak per butir telur cenderung menipis. Hal ini juga turut mendorong peternak membuat program pencampuran makanan dengan biaya rata-rata per kilogram yang relatif rendah untuk tujuan penghematan. 
Heatubun, dkk. 2019: Kualifikasi Manajerial Teknis Produksi Telur...

Berdasarkan data dan informasi di atas serta analisis yang dilakukan peternakan bahwa sesuai kondisi operasional manajemen perusahaan, perusahaan masih memperoleh keuntungan dari program teknis yang dijalankan perusahaan, dan karena itu perusahaan terus berproduksi dengan sistem operasi yang diyakini baik dan menguntungkan perusahaannya.

Tabel 1. Jumlah pemberian jenis-jenis makanan untuk ayam peterlur pada UD. Fitra Abadi

\begin{tabular}{cccccccccc}
\hline Hari & $\begin{array}{c}\text { Q } \\
(\text { btr })\end{array}$ & $\begin{array}{c}\text { RsTk } \\
(\mathrm{kg})\end{array}$ & $\begin{array}{c}\text { PkJgg } \\
(\mathrm{kg})\end{array}$ & $\begin{array}{c}\text { PkDdk } \\
(\mathrm{kg})\end{array}$ & Hari & $\begin{array}{c}\text { Q } \\
(\mathrm{btr})\end{array}$ & $\begin{array}{c}\text { RsTk } \\
(\mathrm{kg})\end{array}$ & $\begin{array}{c}\text { PkJgg } \\
(\mathrm{kg})\end{array}$ & $\begin{array}{c}\text { PkDdk } \\
(\mathrm{kg})\end{array}$ \\
\hline 1 & 1.530 & 76,93 & 114,64 & 56,73 & 17 & 1.777 & 89,01 & 126,63 & 56,56 \\
2 & 1.558 & 80,14 & 110,26 & 49,12 & 18 & 1.784 & 89,56 & 119,73 & 53,13 \\
3 & 1.565 & 79,25 & 131,15 & 44,65 & 19 & 1.784 & 95,89 & 115,88 & 49,39 \\
4 & 1.600 & 79,10 & 123,23 & 50,20 & 20 & 1.816 & 95,51 & 140,29 & 60,51 \\
5 & 1.641 & 81,10 & 129,94 & 53,62 & 21 & 1.839 & 91,50 & 129,31 & 57,53 \\
6 & 1.654 & 85,96 & 112,69 & 46,55 & 22 & 1.828 & 94,51 & 123,64 & 57,12 \\
7 & 1.631 & 80,93 & 130,04 & 42,77 & 23 & 1.837 & 94,42 & 131,56 & 58,17 \\
8 & 1.665 & 83,89 & 140,03 & 49,15 & 24 & 1.820 & 99,28 & 140,22 & 62,51 \\
9 & 1.678 & 88,72 & 132,58 & 53,18 & 25 & 1.814 & 94,39 & 142,77 & 51,72 \\
10 & 1.634 & 87,42 & 154,47 & 55,45 & 26 & 1.828 & 97,56 & 135,70 & 46,61 \\
11 & 1.661 & 88,13 & 120,65 & 44,81 & 27 & 1.851 & 103,00 & 118,67 & 48,75 \\
12 & 1.660 & 87,39 & 132,61 & 56,28 & 28 & 1.856 & 99,31 & 134,61 & 59,58 \\
13 & 1.707 & 89,25 & 128,74 & 41,54 & 29 & 1.859 & 100,97 & 113,86 & 55,30 \\
14 & 1.739 & 90,19 & 120,67 & 53,89 & 30 & 1.873 & 102,89 & 145,61 & 58,31 \\
15 & 1.758 & 87,78 & 114,98 & 51,11 & 31 & 1.883 & 103,35 & 126,57 & 65,39 \\
16 & 1.761 & 88,94 & 149,33 & 48,09 & & & & & \\
\hline \multicolumn{7}{c}{ Rata-rata }
\end{tabular}

Keterangan : $\mathrm{Q}=$ produksi telur (btr); RsTk = ransum toko,

PkJgg = pakan jagung $(\mathrm{kg}) ; \mathrm{PkDdk}=$ pakan dedak $(\mathrm{kg})$.

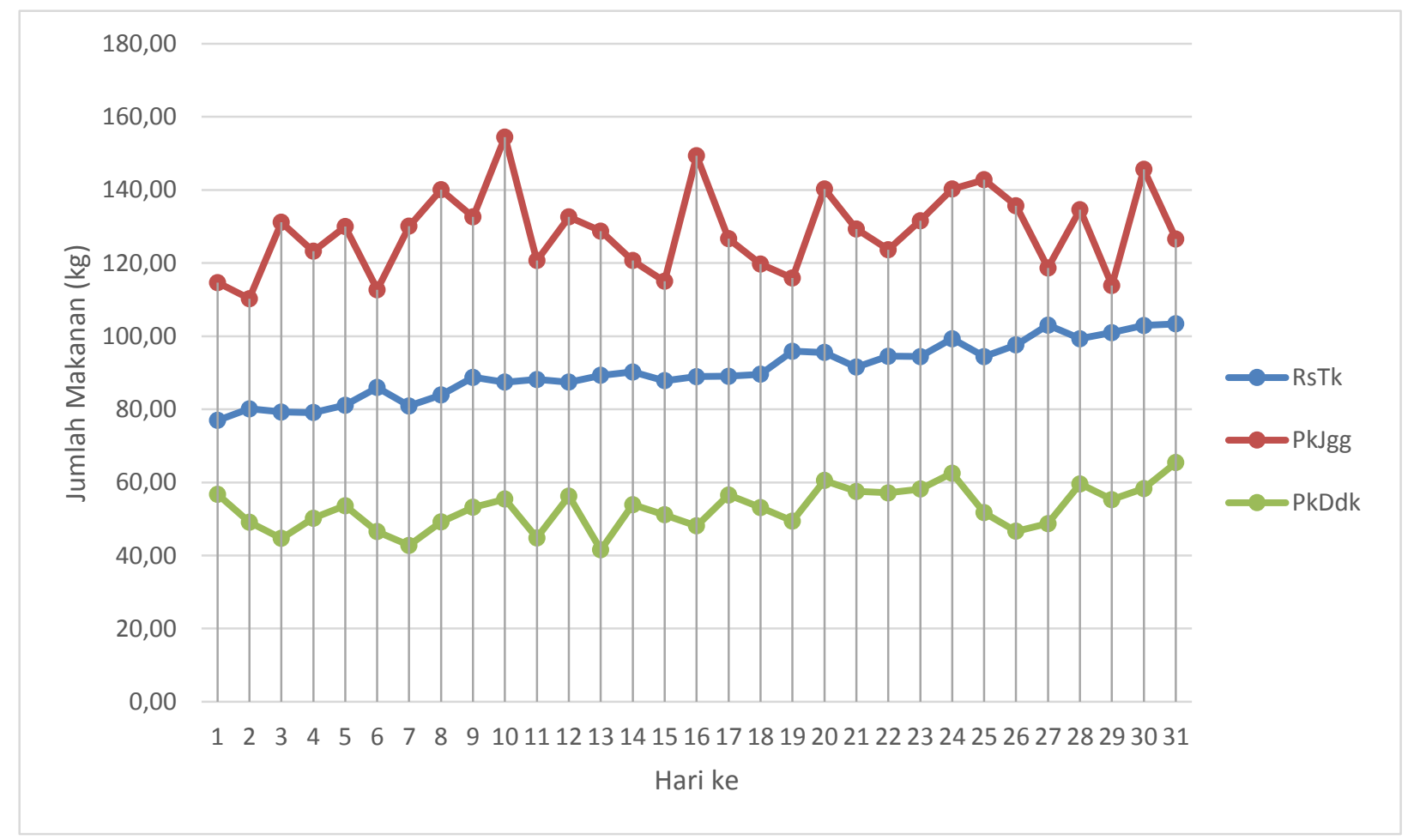

Gambar 1. Perkembangan pemberian jenis-jenis pakan untuk ayam petelur pada UD. Fitra Abadi 


\section{Pemberian Makanan, Produksi Telur, dan Indikator Produktivitas}

Estimasi pemberian makanan oleh peternak setiap hari dan jumlah produksi telur yang diharapkan diperoleh dari 2100 ekor ayam petelur yang dimiliki peternak, merupakan bagian manajemen yang akan menunjukkan keterampilan peternak mengelola perusahaannya dengan berhasil. Pada Tabel dan Gambar 1 disajikan data pemberian jenis-jenis makanan dan jumlahnya serta perkembangan per hari selama satu bulan (31 hari).

Dari data pada Tabel 1 dapat dilihat bahwa jumlah pemberian makanan oleh peternak pada ternak ayam rata-rata per hari sebesar: ransum jadi (toko) 90,52 kg, pakan jagung 128,74 kg, dan pakan dedak sebanyak 52,83 kg. Dari data ini diketahui jenis makan yang dominan diberikan ayam petelur adalah pakan jagung giling. Sementara ransum toko dan pakan dedak dapat dianggap sebagai pelengkap. Informasi data primer penelitian menunjukkan peternak dominan memberikan pakan jagung dengan pertimbangan untuk menghemat biaya makanan, karena harga jagung relatif lebih murah dibanding ransum jadi (toko).

Keputusan manajerial peternak dalam pengaturan makanan ini diambil di tengah ayam petelur berada pada periode puncak bertelur dan antisipasi harga telur di pasaran (saat ini Rp. 2.000 per butir) yang berfluktuasi. Oleh karena harga telur di pasaran dapat saja berubah sementara biaya produksi tidak dapat dihindari maka keputusan mengantisipasi risiko adalah peternak menggantikan pakan jagung lebih banyak dibanding diberi pakan utama ransum toko, asalkan jumlah telur standar (jumlah minimal) dapat dihasilkan.

Melihat trend harian pemberian jenis makanan pada Gambar 1 menunjukkan pemberian ransum jadi (toko) cenderung naik secara stabil per hari. Sedangkan pemberian pakan jagung dan dedak agak berfluktuasi tidak stabil. Meskipun berfluktuasi, jumlah pakan jagung tetap lebih tinggi dibanding kedua jenis pakan lainnya.

Pada Tabel 2 dan Gambar 2 disajikan data jumlah produksi telur per hari, produksi rata-rata dan produksi marginal serta perkembangan produksi telur harian selama satu bulan (31 hari). Data pada Tabel 2 menunjukkan bahwa dari sebanyak2.100 ekor ayam petelur, rata-rata produksi telur yang dihasilkan per hari sebanyak 1.738 butir, jumlah total makanan ratarata per hari sebanyak $272,10 \mathrm{~kg}$, produksi telur ratarata per kilogram makanan sebesar 6,43 butir $/ \mathrm{kg}$, dan marginal produksi yaitu tambahan telur ketika menambah satu kilogram makanan adalah sebesar -0,3 butir telur.

Tabel 2. Jumlah produksi telur, produksi rata-rata, produksi marginal pada UD. Fitra Abadi selama penelitian

\begin{tabular}{|c|c|c|c|c|c|c|c|c|c|}
\hline Hari & $\begin{array}{l}\mathrm{TM} \\
(\mathrm{kg})\end{array}$ & $\begin{array}{c}\mathrm{Q} \\
\text { (btr) }\end{array}$ & $\begin{array}{c}\mathrm{AP} \\
(\mathrm{btr} / \mathrm{kg})\end{array}$ & $\begin{array}{l}\text { MP } \\
\text { (btr) }\end{array}$ & Hari & $\begin{array}{l}\mathrm{TM} \\
(\mathrm{kg})\end{array}$ & $\begin{array}{c}\mathrm{Q} \\
\text { (btr) }\end{array}$ & $\begin{array}{c}\mathrm{AP} \\
(\mathrm{btr} / \mathrm{kg})\end{array}$ & $\begin{array}{l}\text { MP } \\
\text { (btr) }\end{array}$ \\
\hline 1 & 248,30 & 1.530 & 6 & & 17 & 272,20 & 1.777 & 7 & -1 \\
\hline 2 & 239,52 & 1.558 & 7 & -3 & 18 & 262,42 & 1.784 & 7 & -1 \\
\hline 3 & 255,05 & 1.565 & 6 & 0 & 19 & 261,16 & 1.784 & 7 & 0 \\
\hline 4 & 252,53 & 1.600 & 6 & -14 & 20 & 296,31 & 1.816 & 6 & 1 \\
\hline 5 & 264,66 & 1.641 & 6 & 3 & 21 & 278,34 & 1.839 & 7 & -1 \\
\hline 6 & 245,20 & 1.654 & 7 & -1 & 22 & 275,27 & 1.828 & 7 & 4 \\
\hline 7 & 253,74 & 1.631 & 6 & -3 & 23 & 284,15 & 1.837 & 6 & 1 \\
\hline 8 & 273,07 & 1.665 & 6 & 2 & 24 & 302,01 & 1.820 & 6 & -1 \\
\hline 9 & 274,48 & 1.678 & 6 & 9 & 25 & 288,88 & 1.814 & 6 & 0 \\
\hline 10 & 297,34 & 1.634 & 5 & -2 & 26 & 279,87 & 1.828 & 7 & -2 \\
\hline 11 & 253,59 & 1.661 & 7 & -1 & 27 & 270,42 & 1.851 & 7 & -2 \\
\hline 12 & 276,28 & 1.660 & 6 & 0 & 28 & 293,50 & 1.856 & 6 & 0 \\
\hline 13 & 259,53 & 1.707 & 7 & -3 & 29 & 270,13 & 1.859 & 7 & 0 \\
\hline 14 & 264,75 & 1.739 & 7 & 6 & 30 & 306,81 & 1.873 & 6 & 0 \\
\hline 15 & 253,87 & 1.758 & 7 & -2 & 31 & 295,31 & 1.883 & 6 & -1 \\
\hline 16 & 286,36 & 1.761 & 6 & 0 & & & & & \\
\hline \multicolumn{6}{|c|}{ Rata-rata } & 272,10 & 1.738 & 6,43 & $-0,3$ \\
\hline
\end{tabular}

Keterangan : $\mathrm{TM}=$ Total makanan $(\mathrm{kg})$;

$\mathrm{Q}=$ produksi telur (btr),

$\mathrm{AP}=$ produksi rata-rata $(\mathrm{btr} / \mathrm{kg})$;

$\mathrm{MP}=$ marginal produksi (btr). 


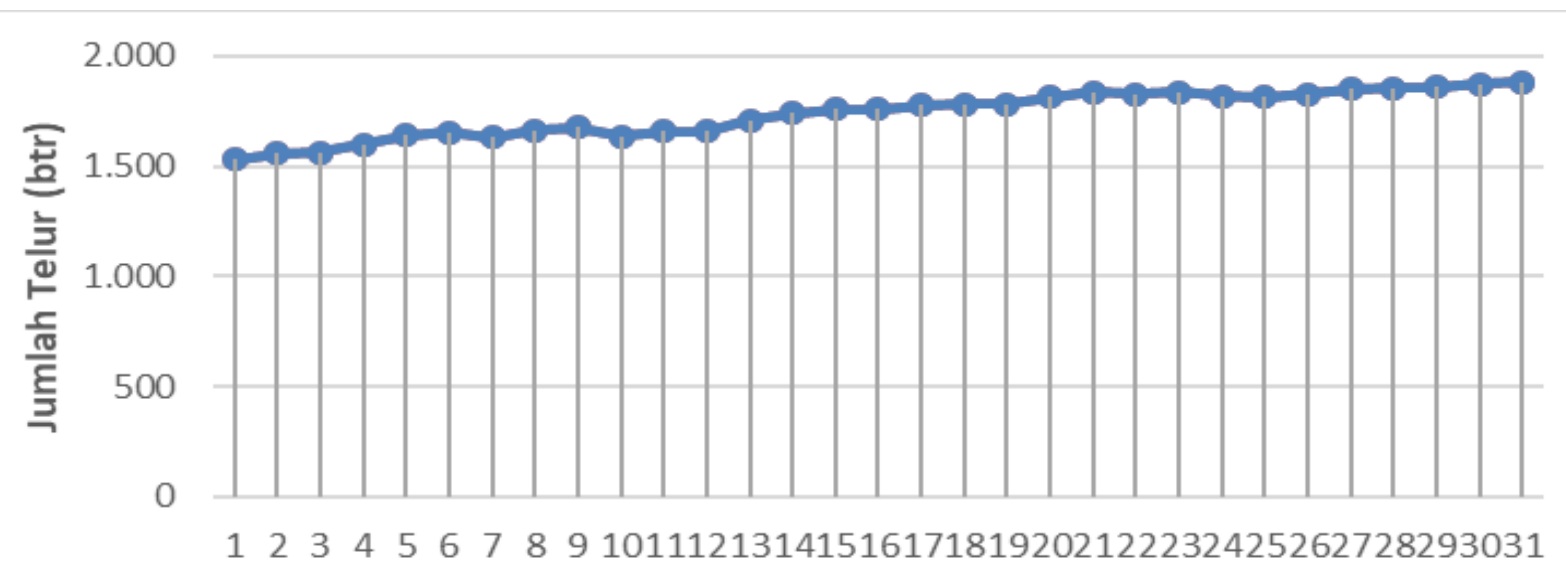

Hari ke-

Gambar 2. Perkembangan produksi telur harian pada UD. Fitra Abadi selama penelitian

Hasil penelitian menunjukan saat penelitian dilakukan kondisi induk ayam petelur pada perusahan UD. Fitra Abadi berada dalam periode puncak periode bertelur yaitu pada umur 28 - 33 minggu. Adnan (2011) menyatakan bahwa ayam petelur pada umur 28 - 35 minggu merupakan periode puncak bertelur, dan dalam kondisi ideal periode bertelur tersebut, produksi telur dapat mencapai rata-rata $95 \%$.

Bila dibandingkan antara jumlah telur rata-rata yang dihasilkan dan jumlah ayam 2.100 ekor, maka ayam petelur masa puncak bertelur pada UD. Fitra Abadi hanya mampu bertelur sebesar 82,76 \% . Hasil yang dicapai perusahaan ayam petelur ini berada jauh di bawah standar seperti yang dinyatakan oleh Adnan (2011) bahwa produksi telur untuk ayam petelur pada umur puncak bertelur adalah rata-rata $95 \%$. Jika dilihat perkembangan produksi telur seperti pada Gambar 2, produksi telur harian agak meningkat secara stabil dari hari ke hari.Namun tidak ada peningkatan kuat pada produksi telur setiap hari, artinya kapasitas produksi telur pada perusahaan UD. Fitra Abadi dari induk ayam yang ada mungkin sudah mencapai maksimum.

\section{Kondisi Teknis Produksi Telur UD. Fitra Abadi}

Produksi rata-rata (average product, AP) dan marginal produksi (marginal product, MP) merupakan dua indikator yang menunjukkan poduktivitas input. Ini berarti sebaik apa kapasitas input telah digunakan untuk menghasilkan produksi melalui proses produksi yang diaplikasikan akan terlihat dari nilai-nilai kedua indikator ini. Produksi rata-rata menunjukkan seberapa banyak jumlah produksi yang dihasilkan dari penggunaan satu unit input. Bilamana penggunaan satu unit input mampu menghasilkan sejumlah besar produksi, itu menunjukkan bahwa unit input yang digunakan memiliki produktivitas yang tinggi. Sebaliknya makin rendah jumlah produksi yang dihasilkan dari satu unit input menunjukkan produktivitas unit input tersebut makin rendah.
Data pada Tabel 2 menunjukkan bahwa produksi rata-rata (AP) yang dihasilkan UD. Fitra Abadi sebesar 6,43 butir/kg. Ini menunjukkan selama 31 hari dengan pencapaian produksi telur rata-rata 1.738 butir dan jumlah total makanan rata-rata 272,10 $\mathrm{kg}$, hanya diperoleh rata-rata produksi telur per $\mathrm{kg}$ makanan sebanyak 6,43 butir. Hasil ini cukup kecil yang menunjukkan produktivitas per $\mathrm{kg}$ makanan cukup rendah. Patut diduga produktivitas rendah dari per $\mathrm{kg}$ makanan ini dapat muncul akibat paket teknologi pencampuran bahan makanan yang tidak mengikuti formulasi zat-zat gizi sesuai kebutuhan ayam petelur pada periode produksi puncak bertelur.

Indikator produktivitas berikutnya adalah marginal produksi. Sesuai data pada Tabel 2, marginal produksi rata-rata selama masa penelitian sebesar -0,3. Nilai marginal produksi ini memiliki arti jika input makanan ditambahkan sebesar $1 \mathrm{~kg}$ di atas rata-rata per hari, akan memberikan tambahan produksi telur sebanyak $-0,3$ butir. Ini menunjukkan bahwa penambahan $1 \mathrm{~kg}$ makanan tidak lagi memberikan tambahan telur melainkan jumlah produksi telur berkurang sebanyak 0,3 butir. Kondisi ini memberikan arti perusahaan UD. Fitra Abadi beroperasi dalam keadaan dimana produktivitas sudah negatif. Karena itu dalam keadaan ini, setiap penambahan satu unit input tidak lagi menghasilkan tambahan produksi.

Konsep elastisitas menunjukkan seberapa besar sensitivitas atau kepekaan perubahan suatu variabel akibat adanya perubahan pada variabel lainnya. Lebih tegas oleh Izekor dan Alufohai (2014) menyatakan elastisitas produksi merupakan degree atau tingkat respon dari output terhadap perubahan unit input yang digunakan, yang dihitung dengan menggunakan fungsi Cobb Douglas. Formula yang dibangun sesuai definisi elastisitas maka elastisitas dapat dirumuskan sebagai MP/AP (Nicholson and Snyder, 2008).

Data pada Tabel 2 menunjukkan nilai AP sebesar 6,43 dan MP sebesar -0,3 maka elastisitas 
produksi pada perusahaan peternakan ayam petelur UD. Fitra Abadi sebesar -0,3/6,43 = -0,047. Elastisitas sebesar $-0,047$ memiliki pengertian bahwa jika input ditingkatkan sebesar $1 \%$ maka output atau produksi menurun sebesar $0,047 \%$. Nilai elastisitas ini menunjukkan perusahaan UD. Fitra Abadi sudah beroperasi pada tahap produksi ketiga atau tahap produksi merugi.

Nilai elastisitas akan menunjukkan apakah setiap penambahan input yang digunakan akan menghasilkan produktivitas yang dengan tingkat constant $(\mathrm{Ep}=1)$, atau increasing $(\mathrm{Ep}>1)$, atau decreasing (Ep < 1) (Izekor dan Alufohai, 2014). Elastisitas produksi UD. Fitra Abadi Ep $=-0,047$ tidak tergolong constant, increasing, atau juga decreasing melainkan merugi. Selanjutnya Gajdzik dan Gawlik (2018) menyebutkan bahwa elastisitas negatif menunjukkan efisiensi produksi bukan lagi constant, increasing atau decreasing melainkan efisiensi produksi negatif.
Berdasarkan data nilai-nilai produksi, pemberian makanan, produksi rata, produksi marginal dan nilai elastisitas, dapat ditunjukkan kondisi teknis produksi telur UD. Fitra Abadi pada Gambar 3.

Sesuai kondisi teknis produksi telur pada perusahaan UD. Fitra Abadi pada Gambar 3 maka perusahaan beroperasi pada fase produksi ketiga (merugi). Diduga kondisi perusahaan ini disebabkan oleh penerapan teknologi pencampuran makanan yang dilakukan perusahaan dengan tujuan menghemat biaya produksi namun komposisi zat-zat gizi akibat pencampuran bahan makanan tidak mendukung kapasitas produksi ayam petelur pada periode puncak bertelur. Akibatnya produksi telur yang dicapai perusahaan berada di bawah potensi standar periode puncak bertelur.

Dalam hal ini perusahaan telah membuat kesalahan manajemen produksi dengan mengejar penghematan biaya produksi tetapi mengorbankan kapasitas produksi yang sudah tinggi dari input - input tetap (ayam petelur).

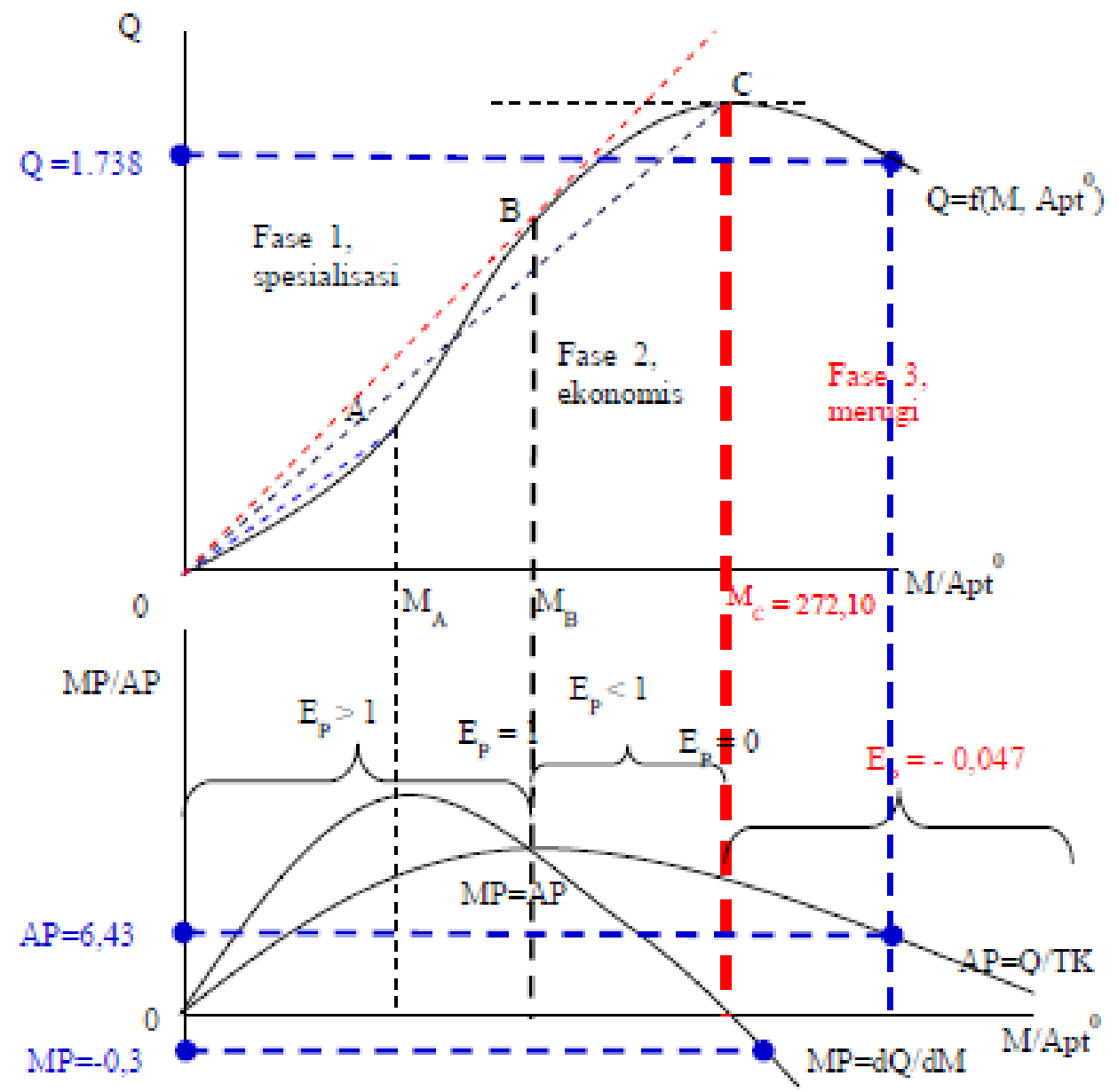

Keterangan $: \mathrm{MP}=$ marjinal produksi $; \mathrm{AP}=$ produksi rata-rata

Gambar 3. Kondisi teknis produksi telur pada perusahaan UD. Fitra Abadi 


\section{SIMPULAN DAN REKOMENDASI}

Dari hasil penelitian dapat ditarik beberapa simpulan sebagai berikut:

1. Perusahaan ayam petelur UD. Fitra Abadi menerapkan paket teknologi pencampuran makanan yaitu paket teknologi lebih rendah kapasitasnya dengan mencampur makanan toko (35\%), pakan jagung $(45 \%)$, dan pakan dedak (20\%).

2. Jumlah makanan toko rata-rata per hari sebanyak $90,52 \mathrm{~kg}$, pakan jagung 128,74 kg, pakan dedak $52,84 \mathrm{~kg}$, dan total makanan sebanyak $272,10 \mathrm{~kg}$.

3. Produksi telur yang dihasilkan rata-rata per hari sebanyak 1.738 butir $(82,76 \%$ dari 2.100 ekor ayam) berada di bawah kapasitas terbaik periode puncak bertelur yaitu $95 \%$.

4. Produksi rata-rata per kilogram makanan 6,43 butir, produksi marginal $-0,3$ butir, dan elastisitas $-0,047$.

5. Efiseinsi produksi perusahaan menjadi negatif, dan perusahaan beroperasi pada fase merugi.

Rekomendasi yang diberikan adalah (1) perusahaan perlu mempertimbang kan untuk mengganti penggunaan paket teknologi yang lebih menguntungkan, dan (2) perusahaan perlu memperbaiki manajemen dan pengetahuan tentang pencampuran bahan makanan yang sudah lengkap komposisi nutrisinya dengan bahan makanan tambahan meskipun harganya murah.

\section{DAFTAR PUSTAKA}

Adnan, K. 2011. Pertumbuhan Berat Badan yang Optimal pada Ayam Petelur/Layer. http://kuntaadnan.blogspot.com./2011/07/pert umbuhan-beratbadan-yang-optimal.html. [11/03/2019].

Aydin, S., A.T Cetin, and G. Ozer. 2007. The Relationship Between Marketing and Product Development Process and Their Effects on Firm Performance. Academy of Marketing Studies Journal. 11 (1): 53-68.
Banaeian, N., and M. Zangeneh. 2011. Estimating production function of walnut production in Iran using Cobb-Douglas method. Agricultura Tropica et Subtropica. 44 (4): 189-201.

Burja, C., and V. Burja. 2016. Farms Size and Efficiency of The Production Factors in Romanian Agriculture. Economics of Agriculture. 63 (2): 361-374.

Chigbo, N. D. 2014. Management as a Factor of Production and as an Economic Resource. International Journal of Humanities and Social Science. 4(6): 162 - 166.

Clercq, D.D., and P. Arenius. 2006. The Role of Knowledge in Business Start-Up Activity. International small business journal. 24(4): 339-358.

Gajdzik, B., and R. Gawlik. 2018. Choosing the Production Function Model for an Optimal Measurement of the Restructuring Efficiency of the Polish Metallurgical Sector in Years 2000-2015. Metals. 8(1): 23-33.

Glendoh, S.H. 2001. Pembinaan dan Pengembangan Usaha Kecil. Jurnal Manajemen \& Kewirausahaan. 3(1): 1-13.

Izekor, O.B., and G. O. Alufohai. 2014. Production Elasticities, Return to Scale and Allocative Efficiency in Yam Production in Edo State, Nigeria. Agrosearch. 14(2): 179-190.

Kristianto, Y., M. Ajmal, R. Addo Tenkorang, and M. Hussain. 2012. A study of technology adoption in manufacturing firms. Journal of Manufacturing Technology Management. 23(2): 198-211.

Nicholson, W., and C. Snyder. 2008. Microeconomic Theory. Basic Principles and Extensions. Tenth Edition. USA: Thomson SouthWestern.

Reiff, A., A. Sugar, and E. Surányi. 2002. Productive Efficiency in The Hungarian Industry. Hungarian Statistical Review. Vol. 7: 45-74.

Available online at journal homepage: http://ojs3.unpatti.ac.id/index.php/agrinimal 